\title{
О КОМСОМОЛЕ 30 ЛЕТ СПУСТЯ
}

\author{
О. В. Ушакова \\ Московский гуманитарный университет
}

Аннотация: В статье автор делится впечатлениями от своего знакомства с комсомольской историей своих родителей, своих коллег.

Ключевые слова: комсомол; воспоминания; мнение

\section{KOMSOMOL 30 YEARS LATER}

\author{
O. V. Ushakova \\ Moscow University for the Humanities
}

Abstract: The paper shares the author's impressions of her acquaintance with the history of Komsomol as told by her parents and colleagues.

Keywords: Komsomol; reminiscence; opinion

Я с комсомолом не связана никак, так как родилась только в 1986 году. Я и октябренком-то не была. И в год, когда я поступила в школу, был первым, когда отменили форму, хотя она уже у меня была. Коричневое шерстяное платье висело на вешалке, его нам отдали друзья родителей, чьи дети из него уже выросли. Но носить его мне не пришлось...

Так что о комсомоле у меня очень расплывчатое представление и то почерпнутое из школьного курса истории середины 1990-х гг.

Все изменил «круглый стол» «Благодаря комсомолу...», посвященный 100-летию ВЛКСМ и проведенный 23 мая 2018 года в стенах бывшей Высшей комсомольской школы, а ныне Московского гуманитарного университета.

По семейной традиции, как мой папа и дедушка, я закончила Российский государственный технологический университет имени К. Э. Циолковского и когда меня спрашивают в каком вузе я училась, старшее поколение чаще всего понимает только, когда произносится «МАТИ». Это был крупный, технический вуз, его знают многие. В 2015 году реорганизован путем присоединения к МАИ. Название сменилось, но, по сути, ничего не поменялось. Поколения помнят вуз как МАТИ. 
Точно также и с ВКШ - МосГУ. Многие помнят университет как ВКШ, и знают, что эти три буквы значили в СССР.

Мне посчастливилось быть причастной к организации этого «круглого стола». По замыслу организаторов, все выступления должны были сопровождаться визуальным рядом фотографий, документов, агитационными плакатами ВЛКСМ. По некоторым темам эти материалы готовила и я.

Поиск в Интернете показал огромный объем архивов, тематических подборок, воспоминаний, подкрепленных фотографиями, книг, статей и очерков. Недостатка в материале не было! И надо сказать, что даже с экрана монитора лица молодых людей, проникнутые возвышенными стремлениями, передают дух времени строительных отрядов, строителей БАМа, иных комсомольских строек и многих других областей, в которых члены ВЛКСМ были задействованы.

А шесть часов мероприятия было словно кратким курсом ожившей истории ВЛКСМ. Я и не могла себе представить, какое сильное впечатление произведут на меня выступления и воспоминания приглашенных руководителей и членов ВЛКСМ.

Более других мне запомнилось речь участника Великой Отечественной войны, генерал-майора в отставке С. А. Тюшкевича. И во многом потому, что в зале он был старейшим представителем молодежного движения. Степану Андреевичу идет 101 год!

В президиуме были Е. М. Тяжельников и Б. П. Пастухов - первые секретари ЦК ВЛКСМ 1968-1982 годов.

После окончания «круглого стола», в этот же день я была у родителей дома и буквально с порога, еще охваченная эйфорией от прошедшего мероприятия, спрашиваю: «А фамилии Тяжельникова и Пастухова вам знакомы?» Мои родители чуть ли не в один голос ответили: «Конечно!» Их комсомольская юность приходилась на то время, когда первыми секретарями ЦК ВЛКСМ были Евгений Михайлович Тяжельников и Борис Николаевич Пастухов. Хотя так получилось, что они, будучи комсомольцами 1970-х и 1980х годов никогда их лично не видели.

Моя мама в 1978 году вступила в комсомол. До того вела активную общественную работу в пионерской организации: в третьем классе была избрана председателем совета отряда, а с четвертого - была членом редколлегии. После вступления в комсомол ее избрали в комитет комсомола школы, где она заведовала сектором печати и организовывала конкурсы школьных газет. С 8 по 10 класс состояла в школе комсомольского актива. За отличную работу в комитете комсомола в 1980 году была премирована путевкой во Всероссийский ордена «Знак почета» пионерский лагерь ЦК ВЛКСМ «Орленок». 
Летом 1985 года моему папе 25 лет. Позади были два грандиозных мероприятия - открытие и закрытие XII Всемирного фестиваля молодежи и студентов в Лужниках в Москве. До моего рождения еще 6 месяцев, а до роспуска ВЛКСМ 6 лет. А пока, ранней весной становится известно, что идейным вдохновителем и главным организатором фестивальных мероприятий будет секретарь ЦК ВЛКСМ Владимир Федосов и надо готовиться выполнять аспирантско-комсомольское поручение: с июля в МАТИ формируется студенческий строительный отряд и два месяца нужно тренировать исполнение динамических картин художественного фона (прямой и самый известный аналог — плачущий Олимпийский мишка). 0 том времени до сих пор напоминает ручной фонарь совершенно фантастической по сегодняшним меркам конструкции и песочного цвета папина стройотрядовская форма и нашивка с «ВССО».

Вот так благодаря комсомолу много лет спустя протянулась ниточка от поколения моих родителей до меня самой!

Дата поступления: 30.08.2018 г.

Ушакова Ольга Владимировна - заведующая отделом мониторинга и внедрения результатов научно-исследовательской работы Управления аспирантуры, докторантуры и научной работы Московского гуманитарного университета. Адрес: 111395, Россия, г. Москва, ул. Юности, д. 5. Эл. адрес: oushakova@mosgu.ru

Ushakova Olga Vladimirovna, Head, Department of Monitoring and Application of the Results of Scientific Work, Office of Post-Graduate and Doctoral Studies, and Scientific Work, Moscow University for the Humanities. Postal address: 5, Yunosti St., Moscow, Russian Federation, 111395. E-mail: oushakova@ mosgu.ru

\section{Для цитирования:}

Ушакова О. В. О комсомоле 30 лет спустя [Электронный ресурс] // Научные труды Московского гуманитарного университета. 2018. № 6. URL: http://journals.mosgu.ru/trudy/article/view/841 (дата обращения: дд.мм.гг.). DOI: $10.17805 /$ trudy.2018.6.10 